\title{
MAKNA SIMBOLIK DIBALIK KAIN LURIK SOLO - YOGYAKARTA
}

\author{
Suprayitno; Inda Ariesta \\ Visual Communication Design, School of Design, BINUS University \\ Jln. K.H. Syahdan No. 9, Palmerah, Jakarta Barat 11480 \\ praysutoyo@binus.ac.id
}

\begin{abstract}
As with another woven in the archipelago, woven Lurik has philosophy values and are also loaded with symbolic meaning. Woven Lurik can not be removed from the people's belief as well as various religious and customs rituals. The purpose of this study is to redescribe the symbolic meaning of the woven Lurik, with a qualitative method approach through the study of literature and interview stages. Philosophy and symbolic meaning of a piece of Lurik normally reflected in the motifs and colors. Woven Lurik with its various pattern is considered to have sacred values that give good luck, advice, guidance, and hope. All of which is reflected in the style sheet / woven motifs.
\end{abstract}

Keywords: woven lurik, the value of philosophy, symbolic meaning

\begin{abstract}
ABSTRAK
Sebagaimana kain tenun lainnya di Nusantara, kain tenun Lurik memiliki nilai-nilai filosofi dan juga sarat dengan makna simbolik. Kain tenun Lurik tidak dapat dilepaskan dari kepercayaan masyarakat sebagaimana halnya upacara ritual keagamaan maupun adat. Tujuan penelitian ini adalah mendeskripsikan ulang makna simbolis pada kain tenun Lurik tersebut, dengan pendekatan metode kualitatif melalui tahapan studi literatur dan wawancara. Filosofi dan makna simbolik sehelai lurik biasanya tercermin dalam motif dan warnanya. Tenun Lurik dengan beragam coraknya dianggap memiliki nilai sakral memberi tuah, dan ada pula yang mensiratkan nasehat, petunjuk, dan harapan. Kesemuanya tercermin dalam sehelai corak / motif kain tenun Lurik.
\end{abstract}

Kata kunci: kain tenun lurik, nilai filosofi, makna simbolik 


\section{PENDAHULUAN}

Teknik maupun hasil tenun sudah sejak dahulu dikenal dan dikerjakan hampir di seluruh pelosok kepulauan Indonesia, sebagai salah satu warisan budaya bangsa yang patut dibanggakan. Terlebih bangsa Indonesia sejak berabad-abad telah menguasai berbagai teknik pertenunan, seperti tenun songket, tenun ikat pakan atau ikat lungsi, dan tenun ikat berganda. Temuan-temuan berupa alat-alat keperluan memintal, menenun dan sebagainya dapat dijadikan sebagai petunjuk akan kekayaan tersebut. Bahkan diperkuat dengan beberapa temuan berbentuk prasasti, arca dan relief pada beberapa candi Hindu, yang memberikan indikasi adanya teknik tenun yang sudah dikenal pada jamannya dan ada pula petunjuk berupa karya sastra.

Dari sekian banyak jenis kain yang terdapat di Indonesia, salah satu yang sangat menarik bagi penulis adalah kain tenun Lurik. Dibalik kesederhanaan tampilan maupun dalam cara pembuatan, ternyata memiliki nilai luhur dan sarat makna. Berbagai kain tenun Lurik di Indonesia tidak hanya sebagai pakaian penutup saja. Namun lebih dari itu, kain tenun Lurik ini sering dikaitkan dengan berbagai makna simbolik kepercayaan serta ikut mengiringi berbagai upacara keagamaan, ritual dan adat. Tenun Lurik dengan beragam coraknya dianggap memiliki nilai sakral dan dapat memberi tuah, ada pula yang mensiratkan nasehat, petunjuk, dan harapan.

Fakta dari berbagai temuan sejarah memberikan petunjuk bahwa kain tenun Lurik telah ada di Jawa sejak zaman prasejarah. Hal ini dibuktikan dengan adanya prasasti peninggalan kerajaan Mataram 851-882 M, yang menunjukkan keberadaan kain Lurik pakan malang. Prasasti Raja Erlangga di Jawa Timur tahun 1033, menyebutkan bahwa kain tuluh watu adalah salah satu nama kain Lurik. Keberadaan tenun di pulau Jawa diperkuat dengan pemakaian tenun pada arca-arca dan relief candi yang tersebar di pulau Jawa.

"Menurut beberapa ahli purbakala, hasil temuan situs prasejarah, antara lain situs Gilimanuk di Bali, Gunung Wingko di Yogyakarta, Melolo di Sumba Timur, membuktikan bahwa pertenunan sadah dikenal di Indonesai sejak zaman pra-sejarah. Demikian pula terlihat pemakaian selendang tenun pada arca terracota asal Trowulan di Jawa Timur, yang diperkirakan berasal dari abad ke 15M (Museum Sonobudoyo, Yogyakarta), serta pemakaian kain tenun pada relief dan arca di berbagai candi”, Djoemena (2000).

\section{METODE}

Penelitian makna simbolik di balik kain Tenun Lurik Solo dan Yogyakarta ini, menggunakan metode kualitatif dengan tahapan sebagai berikut: Tahapan pertama yaitu Survey Literatur maupun Pustaka. Pada tahapan ini penelitian dimulai dari sumber yang sudah ada, antara lain berdasarkan Djoemena (2000), Zumar (2007), Ornamen Nusantara yang disusun oleh Aryo Sunaryo dan literatur penunjang dari internet dan majalah. Tahap kedua yaitu Interveiw atau wawancara dengan narasumber. Pada tahap ini, tim peneliti melakukan wawancara dengan narasumber pemilik rumah tenun, dan Informan dari Balai Besar Tekstil Yogyakarta, serta para pemerhati kain Lurik. Tahap ketiga yaitu pencatatan makna simbolik di balik kain Tenun Lurik. Pada tahapan ini, tim peneliti mendata maupun menyusun ulang pencatatan makna simbolik dari beberapa contoh corak kain tenun Lurik Solo -Yogyakarta. 


\section{HASIL DAN PEMBAHASAN}

Dinamakan Lurik karena berasal dari bahasa Jawa Kuno yakni 'lorek’ yang berarti lajur atau garis-garis belang dapat pula berarti corak. Sesuai dengan namanya, kain tenun ini juga memiliki motif garis-garis yang melambangkan kesederhanaan. Menurut Widodo, (2008), tenun Lurik merupakan tenun yang bermotif garis-garis. Lurik berasal dari istilah Jawa, yaitu 'rik' yang berarti garis. Istilah Lurik hanya digunakan di Jawa, namun dengan istilah yang berbeda, kain tenun yang menyerupai Lurik juga terdapat di Sumatera, Bali, Lombok, Sumba, Timor. Di luar Jawa, tenun Lurik sering digabung dengan teknik lain seperti ikat dan songket. Menurut Dhorofi (2007), "Lurik pada dasarnya berupa susunan garis-garis dari berbagai warna yang membentuk barisan ragam hias. Garis-garis yang lurus mengesankan ketegasan dan kedinamisan. Corak Lurik merupakan ucapan kekuatan dan semangat pantang menyerah warga Jawa tengah dalam menghadapi kehidupan mereka”.

Pada jaman dahulu, kain Lurik ditenun dengan menggunakan benang katun yang dipintal dengan tangan dan ditenun menjadi selembar kain dengan alat yang disebut 'gedog', alat ini menghasilkan kain dengan lebar $60 \mathrm{~cm}$ saja. Alat tenun yang digunakan pun cukup sederhana yakni bernama bendho dan tenun gendong. Keduanya terbuat dari bambu atau batang kayu. Disebut alat tenun bendho karena alat yang digunakan untuk merapatkan benang berbentuk bendho (golok) sedangkan untuk gendong karena salah satu bagiannya diletakkan di belakang pinggang saat menenun. Dalam perkembangannya saat ini, proses pemintalan kain katun sudah dilakukan secara modern dengan menggunakan mesin. Salah satu ciri khas dari kain Lurik adalah penggunaan benang katun yang akan menghasilkan tekstur yang khas pada kain Lurik ini. Sehingga sebuah kain bermotif Lurik yang dipintal dari benang polyester, tidak dapat disebut sebagai kain Lurik, karena teksturnya akan sangat berbeda dengan kain Lurik yang terbuat dari katun. Seiring dengan perkembangan jaman pula, kain Lurik mulai diproduksi dengan menggunakan ATBM /Alat Tenun Bukan Mesin yang lebih modern dan dapat menghasilkan kain dengan lebar 150cm.

Kain tenun Lurik dengan teksturnya yang khas, memiliki kelenturan serta kekuatan yang baik, sehingga penggunaannya tidak terbatas hanya pada pemakaian sehari-hari saja seperti baju ' $k l a m b i$ ' atau kain gendong saja, namun dapat juga digunakan sebagai perlengkap interior ruangan. Keunikan dari kain Lurik adalah ketika masih baru teksturnya memiliki permukaan sangat kasar dan kaku, namun ketika telah digunakan beberapa lama, teksturnya dapat berubah menjadi lebih lembut namun tidak berkurang kekuatannya.

Motif kain tenun Lurik pun masih sangat sederhana pada awal kehadirannya. Dibuat dalam warna terbatas hanya hitam dan putih atau kombinasi keduanya, kemudian mulai berkembang dengan menggunakan beragam corak warna. Proses pembuatan Lurik juga sangat sederhana. Dimulai dengan menyiapkan benang yang berasal dari tumbuhan perdu dan warna dominan hitam dan putih. Benangpun diberi rendaman daun pohon tom yang menghasilkan warna nila, biru tua dan hitam serta coklat dari batang mahoni. Perbedaan antara satu corak dengan corak lainnya adalah susunan/komposisi warna dan jumlah garis, misalnya Lurik telupat /tiga-empat, coraknya terdiri dari 3 garis dan 4 garis berwarna biru tua yang berselang-seling, dengan kain berwarna dasar hitam. Angka 3 dan 4 apabila dijumlahkan akan menjadi 7 sebagai angka keramat dalam kepercayaan tradisional Jawa. Selain itu bagi masyarakat Jawa angka 7 juga melambangkan kemakmuran. Masing-masing komposisi warna dan garis pada kain lurik memiliki makna tertentu. Seperti kain Lurik gedog madu, digunakan pada upacara mitoni atau siraman; kemudian ada lagi kain Lurik motif lasem umumnya digunakan untuk perlengkapan pengantin.

Kain tenun Lurik umumnya digunakan untuk pakaian sehari-hari. Namun corak/motif Lurik pun dibedakan untuk kalangan keraton dan masyarakat umum. Untuk wanita biasanya dibuat kebaya atau kain bawahan. Sedangkan untuk pria dipakai untuk beskap atau surjan. Selain itu Lurik juga 
seringkali digunakan untuk berbagai upacara kepercayaan seperti labuhan, ruwatan, siraman, mitoni dan lain-lain. Meskipun motif dasar lurik hanya berupa garis, namun Lurik memiliki banyak variasi dan ragam corak atau motif seperti corak klenting kuning, sodo sakler, lasem, tuluh watu, lompong keli, kinanti, kembang telo, kembang mindi, melati secontong, ketan ireng, ketan salak dan lain-lain. Perpaduannya pun tidak hanya garis melainkan juga kotak-kotak, dua garis vertikal serta horizontal.

Filosofi dan makna sehelai Lurik biasanya tercermin dalam corak/motif dan warna kain tenun Lurik tersebut. Ada corak-corak yang dianggap sakral yang memberi nilai tuah, ada yang memiliki nilai nasehat, petunjuk dan juga harapan. Seperti daur kehidupan manusia mulai dari lahir hingga saat meninggal, dapat diibaratkan dengan putaran empat penjuru mata angin yang bergerak dari timur ke selatan dengan melalui barat menuju ke utara. Keempat penjuru mata angin ini dalam bahasa Jawa disebut dengan istilah 'mancapat'. Lurik juga tidak terlepas dari berbagai mitos yang tumbuh dan berkembang secara turun temurun dalam kelompok masyarakat. Berbagai unsur seperti warna, motif, dan kepercayaan yang menyertainya membuat nilai sebuah Lurik kian menjadi tinggi. Penggunaan kain tenun Lurik terutama di daerah Solo dan Yogya, umumnya dipakai dalam penyelenggaraan upacara tertentu, dan juga memiliki makna yang berbeda-beda, tergantung dari maksud dan tujuan upacara yang diselenggarakan.

Kain tenun Lurik ini merupakan sebuah warisan kekayaan intelektualitas serta kreativitas leluhur. Kesederhanaan yang terpancar dari motif kain tenun Lurik dengan berbagai maknanya yang mendalam, merupakan perwujudan dari nilai-nilai kebudayaan yang ditanamkan dari para leluhur kepada generasi berikutnya. Bahkan, keberadaan kain tenun Lurik hingga saat ini merupakan cerminan apresiasi generasi penerus terhadap karya seni budaya bangsa. Tampilan permukaan pada tekstur sehelai kain tenun Lurik, dapat ditentukan oleh: (1) Jenis bahan baku, apakah serat kapas, serat kayu, serat sutera, ataupun serat sintetis. (2) Jenis pintalan, apakah benang pintal tangan atau pintal mesin. (3) Jenis benang, besar kecilnya benang akan mempengaruhi kehalusan tenunan. (4) Jenis alat tenun, apakah menggunakan alat tenun gendong, ATBM atau ATM.

Kain Tenun Lurik produksi Solo, Yogyakarta dan sekitarnya berbentuk: (1) Jarit atau Kain Panjang. Kain panjang berukuran satu meter kali dua setengah meter. Biasanya kani panjang ini mempunyai tumpal yang terdiri dari batuk dan seret untuk kanan kiri, telisir untuk pinggir kain bagian atas dan bawah dan badan kain terletak di tengah. (2) Kain Sarung. Kain sarung mempunyai tumpal lebar 60 centimeter, telisir untuk pinggir kain bagian atas, bawah dan badan sarung. Umumnya berukuran 1 meter kali 2 meter. (3) Kain Ciut (sempit). Kain Ciut atau kain kemben berukuran setengah meter kali dua meter atau tiga meter. umumnya berukuran setengah meter kali tiga meter. Telisir lebih kecil menggunakan benang ganda agar lebih kuat, dan biasa digunakan untuk selendang gendong. (4) Stagen atau ikat pinggang. Stagen berukuran $15 \mathrm{~cm}$ x $350 \mathrm{~cm}$, biasanya digunakan saat mengenakan kain panjang. (5) Bakal Klambi (bahan pakaian). Biasanya berukuran satu meter kali dua setengah meter, tanpa tumpal. Bakal klambi ini digunakan untuk busana daerah, seperti Surjan dan Sruwal (celana prajurit Kraton Yogyakarta).

Sebagaimana telah diungkapkan bahwa sudah sejak dahulu tenun Lurik merupakan kerajinan pakaian rakyat, sedangkan batik yang lebih muda usianya dianggap lebih tinggi tingkatannya dan bersumber dari kalangan keraton. Anggapan tersebut diatas tidak seluruhnya benar. Pada dasarnya kain Lurik juga dipakai oleh kaum ningrat dan masih dipakai hingga sekarang. Terutama pada peristiwa tertentu terlihat pemakaian kain Lurik dengan corak dengan makna tertentu terkait dengan peristiwa adat maupun upacara tradisional di Yogyakarta.

Produk kerajinan kain tenun ATBM menggunakan alat manual yang sebagian besar menggunakan tenaga manusia sebagai penggeraknya. Produk tenun menjadi unik dan menarik ketika melihat proses rangkaian benang menjadi satu kesatuan tenunan kain, selendang ataupun lap makan yang indah. Benang yang dipakai pun berbeda sesuai dengan jenis produknya. Mulai dari benang yang kasar hingga halus, dapat terlihat dari hasil tenunannya. 
Istilah yang perlu diketahui dalam pertenunan yaitu 'benang lusi' dan 'benang pakan'. Benang lusi adalah benang kain tenun yang terletak memanjang kearah panjang kain. Dalam proses pembuatan kain, benang lusi ini banyak mengalami ketegangan dan gesekan. Oleh karena itu benang lusi harus dibuat sedemikian rupa dan kuat sehingga mampu menahan tegangan dan gesekan. Umumnya untuk memperkuat benang lusi dengan menggunakan benang rangkap dan di-gintir. Jika berupa benang tunggal, maka sebelum dipakai harus diperkuat terlebih dahulu melalui proses penganjian (diberi kanji). Benang pakan adalah benang melintang ke arah lebar kain tenun. Benang ini mempunyai kekuatan yang relatif lebih rendah daripada benang lusi.

Masing-masing komposisi warna dan garis pada tenun Lurik memiliki nama tertentu. Seperti komposisi garis dan warna Lurik 'telupat' akan berbeda dengan corak 'sulur ringin', berbeda pula dengan corak 'sodo sak ler' dan sebagainya. Kain Lurik polos yang hanya memiliki corak garis melintang di bagian kedua ujungnya disebut kain 'pankung'. Kain bercorak garis-garis dan berwarna hitam dan putih atau hijau dan putih disebut 'pulowatu'. Sedangkan kain Lurik yang disebut kain 'pribul' memiliki kombinasi dua atau tiga buah garis dan kain namanya terdiri dari beberapa garis yang memiliki beberapa gradasi dari satu warna yang sama.

Ada satu jenis kain Lurik yang lebarnya hanya 15 sentimeter yang memiliki tenunan sangat rapat dan dibuat pada alat tenun kecil. Kain itu disebut kain 'bendho' dan umumnya berwarna hitam, hijau tua atau merah tua sebagai 'stagen'. Kain tenun Lurik memiliki banyak filosofi, semua pengerjaannya masih konvensional mulai dari pemintalan benang hingga penenunan dilakukan secara manual dan tradisional. Bahan baku yang berasal dari benang ini kemudian dipintal oleh sejumlah pekerja yang sudah tidak lagi muda. Setelah proses pemintalan 'ngelos' dilakukan, kemudian dilanjutkan penggabungan sejumlah benang yang berbeda warna untuk menjadi dasar dari proses penenunan, untuk kemudian dilakukan proses penenunan. Meskipun terlihat sederhana motifnya, namun ketrampilan dan kejelian dalam memadukan warna serta tata susunan kotak dan garisnya tampak serasi dan seimbang. Sehingga akan menghasilkan kain Lurik yang indah dan mengagumkan.

Modifikasi kain Lurik menjadi beragam produk, seperti pakaian maupun aksesori semakin digemari masyarakat. Kekhasan corak kain Lurik tradisional dan proses pembuatannya yang masih konvensional dengan tangan, menyebabkan nilai jual produk kain Lurik menjadi tinggi. Tak hanya pasar dalam negeri, kain lurik pun mulai merambah pangsa luar negeri. Sebelum ada upaya modifikasi, kain Lurik sering kali dianggap kuno, tidak trendi, dan kusam. Kini, beragam gerai kerajinan seperti Lawe mulai memberikan sentuhan inovasi baru lewat pewarnaan yang lebih cerah dengan beragam motif. Namun, pembuatan kain Lurik masih tetap dipertahankan secara tradisional dengan penggunaan alat tenun bukan mesin.

Pada masyarakat tradisional khususnya kain tenun selain memiliki fungsi praktis, yang juga memiliki fungsi lain, yakni sebagai sebuah simbol status. Beberapa motif maupun corak Lurik tertentu memiliki kandungan nilai makna harapan. Pakaian yang dikenakan seorang bangsawan dengan status sosial tinggi tentu akan berbeda dengan rakyat biasa dengan status sosial rendah, baik dalam bentuk model maupun coraknya. Begitu pula pakaian yang dipakai dalam upacara tertentu akan sangat berbeda dengan yang pakainan keseharian.

Menurut Sugeng (2013), kata simbol berasal dari bahasa Yunani yaitu 'symbolom' yang berarti tanda atau ciri yang memberitahukan sesuatu kepada seseorang. Simbol merupakan bagian terkecil dari ritual yang menyimpan suatu makna dari tingkah laku atau kegiatan pada upacara ritual yang bersifat khas.

Pemahaman terhadap simbol dapat diidentifikasi sebagai kata benda, kata kerja dan kata sifat. Simbol sebagai kata benda dapat berupa barang, objek, tindakan dan hal-hal konkret lain. Simbol sebagai kata kerja dapat berfungsi untuk menggambarkan, menyelubungi, mengartikan, menunjukkan, memanipulasi, dan menandai. Simbol sebagai kata sifat berarti sesuatu yang lebih besar, lebih 
bermakna, lebih bernilai, dalam sebuah kepercayaan. Fungsi simbol digunakan untuk menjebatani objek atau hal-hal yang nyata dengan hal-hal yang abstrak yang maknanya melebihi dari makna hal yang tampak. Sesuai dengan keragaman karakter maupun status seseorang, maka pakaian yang digunakan juga beragam serta bervariasi. Pada masyarakat yang masih menjunjung tinggi nilai-nilai tradisi seperti pada beberapa kelompok suku bangsa di Indonesia, pakaian yang digunakan menunjukkan identitasnya. Sehingga pakaian bukanlah benda semata-mata atau materi yang dipakai tanpa memiliki makna apapun. Kain lurik misalnya, merupakan sebuah simbol, karena ia memiliki kandungan makna. Simbol merupakan tanda yang dapat ditafsirkan. Makna tersebut merupakan sesuatu yang tidak kasatmata, tetapi maknanya dapat ditafsirkan dibalik corak kain tenun Lurik tersebut.

Simbol merupakan segala sesuatu benda, peristiwa, tindakan, ucapan, dan sebagainya yang telah dilekatkan makna tertentu. Sehingga simbol bukanlah milik individu, namun menjadi milik suatu entitas masyarakat tertetntu. Kain tenun lurik merupakan salah satu benda budaya karena dimiliki oleh suatu masyarakat tertentu. Benda ini merupakan wujud fisik dari ide, nilai, maupun norma yang mengatur dan memberi arah bagi masyarakat pada suatu kebudayaan tertentu.

Menurut Wahyono (1981), Lurik juga dipergunakan sebagai benda upacara penting, bukan hanya kain tenun Lurik, melainkan juga alat-alat tenun seperti kisi, suri, lawon, bahkan klinden (tali pada jantra) dan tali gun dianggap sebagai tolak penyakit. Fungsi kain tenun Lurik antara lain: (1) Corak liwatan, sulur ijo, gedog untuk sesaji ruwatan, atau mitoni. (2) Corak palen dipakai untuk seserahan. (3) Corak dringin dipakai dalam upacara labuhan. (4) Lurik mresik dipakai untuk wanita yang sudah dewasa tetapi belum kawin. (5) Lurik dengkik dengan kemben lurik mrutu sewu dipakai lanjar (janda muda) di daerah wonogiri. (6) Lurik kantil dipakai wanita yang sudah memiliki keturunan sampai generasi ke-5 (wareng) di daerah Bagelan. (7) Lurik gembung limasan di pakai para lanjar.

\section{Beberapa Makna Simbolik Corak Lurik}

Meskipun corak /motif kain tenun Lurik hanya terdiri dari garis-garis dan kotak-kotak, namun terkandung banyak makna simbolik. Hal ini karena Lurik mempunyai makna tradisi, adat kepercayaan bagi orang Jawa baik di kalangan ningrat maupun kalangan rakyat biasa. Pada kain Lurik pemakaian berbagai corak ada kaitan dengan sifat upacara, kedudukan sosial serta keadaan seseorang, apakah seorang wanita, pria, muda, tua, perawan, perjaka atau sudah menikah. Ada beberapa corak mengandung perlambang sekumpulan harapan, diantaranya:

\section{Corak Kluwung}

Kluwung adalah pelangi, pelangi merupakan keajaiban alam dan tanda kebesaran Tuhan Sang Pencipta. Oleh sebab itu Lurik corak kluwung dianggap sakral serta mempunyai tuah sebagai tolak bala. Secara simbolis corak kluwung dilukiskan dengan garis-garis lebar beraneka warna bagaikan warna pelangi. Corak ini dipergunakan untuk berbagai upacara sakral dalam daur kehidupan manusia antara lain: (1) Upacara Mitoni, agar anak yang dikandung lahir selamat terhindar dari bala. (2) Upacara Labuhan, biasanya dilakukan oleh kerabat keraton untuk keselamatan. (3) Upacara Mantenan, biasanya diletakkan dibawah bantal penganten dengan harapan kedua mempelai mencapai keselamatan dan kebahagiaan dalam berumah tangga seperti pesona warna pelangi. 


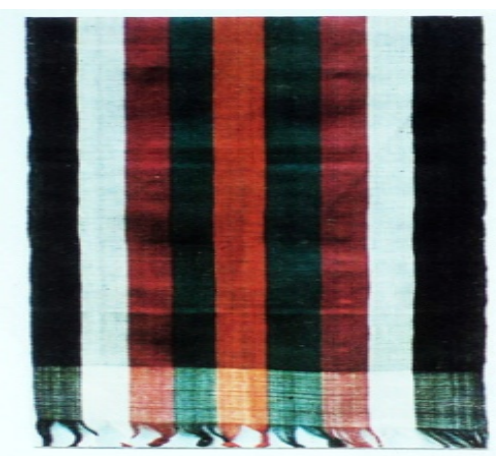

Gambar 1 Corak Lurik Kluwung, Sumber Nian S. Djoemena

\section{Corak Tuluh Watu}

Tuluh Watu berarti 'batu yang bersinar' dan dianggap bertuah sebagai penolak bala. Corak ini biasanya dipergunakan pada upacara Ruwatan Sukerta dan sebagai pelengkap sesajen upacara Labuhan. Tuluh dapat berarti pula kuat atau perkasa. Corak Tuluh Watu termasuk corak sakral yang dahulu hanya boleh dipakai oleh orang tertentu yang berkepribadian kuat dan berbudi luhur. Di pedesaan kaum wanita pedagang memakai corak ini dalam bentuk selendang untuk membawa barang dalam tugas sehari-hari karena mempunyai kekuatan juga sifat tenunannya kuat.

Dhorofi (2007) menambahkan fungsi tenun Lurik tradisional Yogyakarta dengan motif teluh watu atau 'batu bersinar' dianggap bertuah dan berfungsi sebagai tolak bala. Sampai sekarang teluh watuh digunakan untuk upacara labuhan yang diadakan setiap tahun baru Jawa di pantai laut selatan.

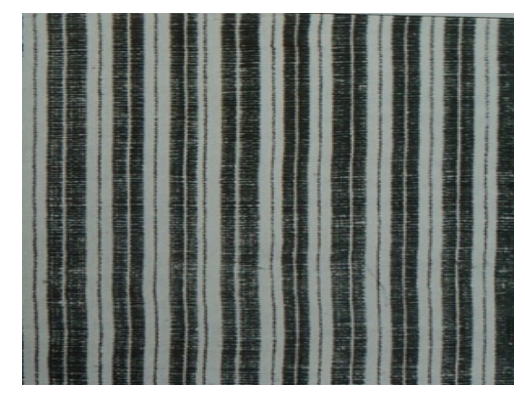

Gambar 2 Corak Lurik Tuluh Watu, Sumber Nian S. Djoemena

\section{Corak Tumbar Pecah}

Corak Tumbar Pecah diibaratkan orang memecah ketumbar dan seharum aroma ketumbar. Corak ini digunakan untuk upacara tingkeban atau mitoni dengan maksud agar kelahiran berjalan dengan lancar semudah memecah ketumbar, ibu dan anak dalam keadaan selamat dan kelak anak menjadi anak yang berguna dan harum namanya. 


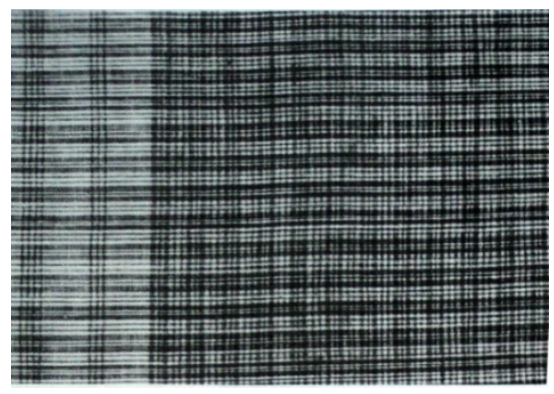

Gambar 3 Corak Lurik Tumbar Pecah, Sumber Nian S. Djoemena

\section{Corak Lompatan atau Liwatan (Solo)}

Lompatan artinya terlewatkan dari bahaya maut. Corak Lompatan biasanya digunakan sebagai kemben kelengkapan upacara mitoni. Untuk upacara mitoni biasanya dililitkan stagen bangun tolak sebagai pengikat kain panjang dan kemben pada perut ibu yang hamil sebagai penolak bala.

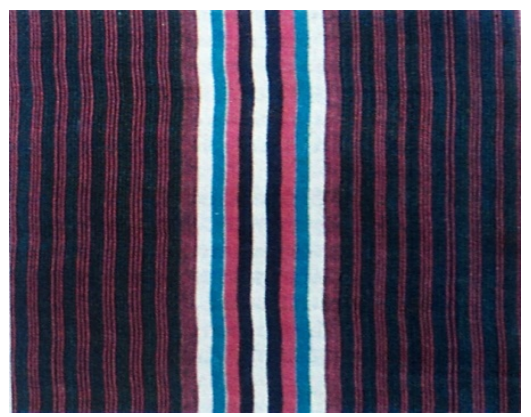

Gambar 4 Corak Lurik Lompatan/Liwatan, Sumber Nian S. Djoemena

\section{Corak Telupat}

Corak telupat berasal dari bahasa Jawa, telu artinya tiga dan papat artinya empat adalah corak lajuran yang berjumlah 7/tujuh terdiri dari satu kesatuan kelompok dengan empat lajur dan satu lagi dengan jumlah tiga lajur. Angka 7 merupakan angka keramat yang dalam kepercayaan tradisional Jawa melambangkan kehidupan dan kemakmuran yang artinya merupakan pitulungan atau pertolongan dari yang Maha Kuasa. Corak ini diciptakan oleh Sri Sultan HB I.

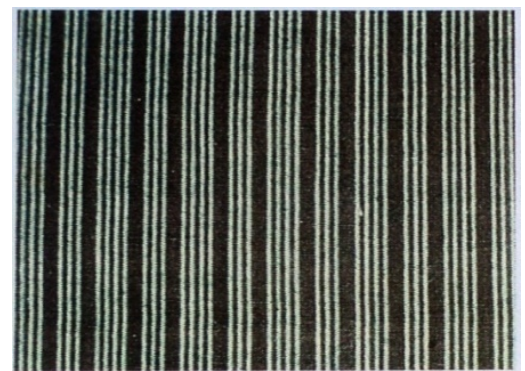

Gambar 5 Corak Telupat, Sumber Nian S. Djoemena 


\section{Corak Sapit Urang}

Corak sapit urang yang berati jepit udang, adalah ungkapan simbolik suatu siasat perang, yaitu musuh dikelilingi atau dikepung dari samping dengan kekuatan komando menyerang berada di tengah-tengah. Corak ini umumnya dipakai sebagai busana prajurit keraton.

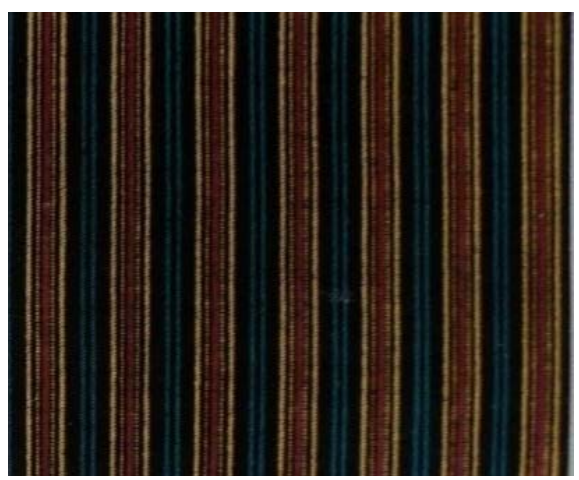

Gambar 6 Corak Sapit Urang,

Sumber Nian S. Djoemena

\section{Corak Udan Liris}

Corak udan liris artinya hujan gerimis, karena hujan mengandung konotasi mendatangkan kesuburan, maka corak ini merupakan lambang kesuburan dan kesejahteraan. Oleh karena itu pula corak udan liris merupakan salah satu corak yang dipakai oleh penguasa, dengan harapan si pemakai diberkahi oleh yang Maha Kuasa dan membawa kesejahteraan bagi para pengikutnya. Selain corak tersebut masih ada beberapa corak yaitu, corak mantri anom, corak prajurit ketanggung, corak prajurit mantri jeron. Semua corak ini yang biasa dipakai untuk pakaian surjan para prajurit keraton Yogyakarta dalam tugas sehari-hari di keraton.

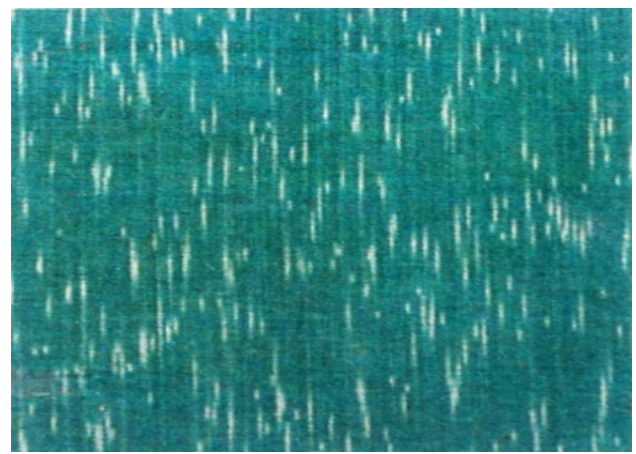

Gambar 7 Corak Udan Liris, Sumber Nian S. Djoemena

\section{Corak Dringin}

Corak Lurik dringin, kain ini mengandung makna agar anak yang dilahirkan kelak mempunyai jiwa rendah hati, sederhana, dan bisa membaur di dalam masyarakat. 

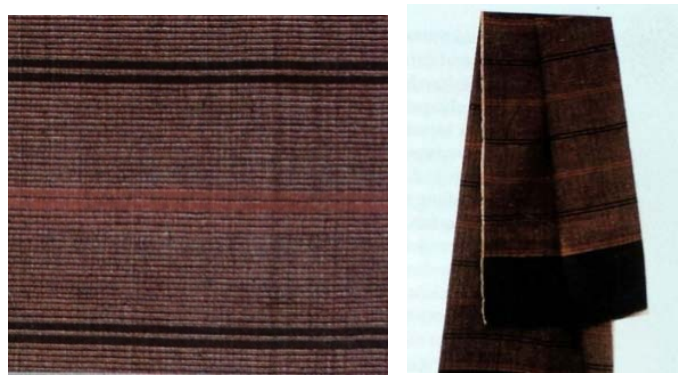

Gambar 8 Corak Dringin, Sumber Nian S. Djoemena

\section{SIMPULAN}

Bangsa Indonesia memiliki kekayaan kearifan lokal yang sangat kreatif dan memiliki citra seni yang sangat tinggi. Hal tersebut tercermin dari hasil olah karya seni. Semisal pada kain tenun Lurik tersebut, detail artistik pada kain tenun Lurik semakin membuktikan bahwa buah kreasi anak bangsa memang sangat eksklusif, patut dibanggakan dan wajib dilestarikan.

Meskipun motif dasar kain tenun Lurik hanya berupa garis-garis, namun kain tersebut memiliki banyak variasi dan ragam motik seperti corak klenting kuning, sodo sakler, lasem, tuluh watu, lompong keli, kinanti, kembang telo, kembang mindi, melati secontong, ketan ireng, ketan salak dan lain-lain. Paduannya pun tidak hanya melulu garis melainkan juga kotak-kotak, dua garis vertikal serta horizontal. Simbol yang terwujud dalam benda-benda budaya khususnya kain tenun Lurik tersebut merupakan sesuatu yang penting bagi masyarakat pendukungnya. Diharapkan, melalui kain Lurik ini terdapat pesan, nasihat dan panduan hidup yang ingin disampaikan, yang nantinya dapat terus menerus ditularkan kepada generasi berikutnya. Aplikasi pada kajian berikutnya dengan objek yang sejenis, masih sangat terbuka dan dapat dilanjutkan.

\section{DAFTAR PUSTAKA}

Dhorifi, Z. (2007). Tenun Tradisional Indonesia. Jakarta: Dewan Kerajinan Nasional

Djoemena, N. S. (2000). Lurik, Garis-garis Bertuah. Jakarta: Djambatan

Sugeng. (2013), Makna Simbolik motif-motif Batik Upacara Adat Mitoni di Yogyakarta. Skripsi tidak diterbitkan, Yogyakarta: Universitas Negeri Yogyakarta

Wahyono, M. (1981). Lurik: Suatu Pengantar. Jakarta: Wastaprema

Widodo, S. T. September - Desember (2008). Produksi Tenun ATBM dengan Aplikasi dan Variasi Pakan Non Benang. Jurnal ARS - Jurnal Seni Rupa Dan Desain, 9,24, ISBN 1829-7412. FSR - ISI Yogyakarta 